\title{
Refugee Status Determination in Brazil: A Tripartite Enterprise
}

\author{
LILIANA LYRA JUBILUT \\ AND \\ Silvia Menicucci de Oliveira Selmi Apolinário
}

\begin{abstract}
Refugee Status Determination (RSD) in Brazil is nowadays a tripartite enterprise, involving UNHCR, the Brazilian government, and civil society. This tripartite character, and especially the participation of the civil society is an impressive feature of RSD in Brazil. It thus seems to be a practice that should be analyzed to see if indeed it can be regarded as a "best practice." In light of this, the paper aims to verify whether or not there are lessons to be learned from RSD in Brazil with a view to improve best practices of RSD in general.
\end{abstract}

\section{Résumé}

Le régime de détermination du statut de réfugié (DSR) au Brésil est couramment un arrangement tripartite, engageant le HCR, le gouvernement brésilien et la société civile. Ce caractère tripartite, tout particulièrement la participation de la société civile, semble être le point saillant de la DSR au Brésil. Par conséquent, c'est là une façon de faire les choses qui mérite d'être examiné de plus près afin de vérifier si on peut vraiment la considérer comme une "pratique exemplaire ". Au vu de ce qui précède, cet article vise à vérifier s'il y a des leçons à tirer de la DSR au Brésil, et cela dans le but d'améliorer les pratiques exemplaires de la DSR en général.

\section{Introduction}

International refugee law, especially the 1951 Convention relating to the Status of Refugees (Refugee Convention) and its 1967 Protocol, defines who is a refugee. To enable States Parties to these treaties to implement their provisions, refugees have to be identified. The determination of refugee status, although mentioned in article 9 of the Refugee Convention, is not specifically regulated and each State Party can establish the procedure that it deems most appropriate, considering its particular constitutional structure.

With regard to refugee law and protection, Brazil can be seen as both an "old" and a "new" country. ${ }^{1}$ It is an "old" country insofar as Brazil was involved in the first international initiatives of refugee protection, ${ }^{2}$ has been a member of the Executive Committee (ExCom) of the United Nations High Commissioner for Refugees (UNHCR) since 1958, and ratified the 1951 Refugee Convention and its 1967 Protocol in 1961 and 1972, respectively. ${ }^{3}$ And it is a "new" country given that the National Refugee Act, Law 9.474, ${ }^{4}$ was passed in 1997 and that in the beginning of the twenty-first century it became an emerging resettlement country. ${ }^{5}$

As the most important developments have occurred in the last decade or so, one can see that refugee law and protection in Brazil has evolved significantly in a short period of time. However, there is always room for improvement.

Refugee status determination (RSD) in Brazil is nowadays a tripartite enterprise, involving UNHCR, the Brazilian government, and civil society. The involvement of civil society is a heritage from the early beginnings of refugee protection in Brazil, when there was no government procedure in place and UNHCR had to rely heavily on civil society in order to guarantee any form of protection whatsoever.

This tripartite character, and especially the participation of civil society, seems to be an impressive feature of RSD in Brazil as it guarantees a more democratic procedure and involves all actors needed to ascertain integral protection to refugees. It thus seems to aid in the establishment of a better RSD protection and is a practice that should be analyzed to see if indeed it can be regarded as a "best practice."

In light of the above, this paper aims to describe the practice of RSD in Brazil, assess its main qualities and flaws, and verify whether or not there are lessons to be learned from RSD in Brazil with a view to improve best practices of RSD in general. 
To achieve these aims, this article is divided into three parts. The first part will provide an overview of RSD in Brazil, both before and after the National Refugee Act of 1997. The second will analyze RSD procedures in Brazil, through three lenses: the internal context in which they occur; the general norms of international refugee law in relation to RSD; and the most protective standards that should apply to the protection of human beings in light of an holistic approach to international law and international human rights law. And finally, the paper will assess if and how the experience of RSD in Brazil can assist in the development of a better-structured RSD system in the world.

\section{RSD in Brazil before the 1997 National Refugee Act} The 1997 National Refugee Act was a turning point in the history of refugee law and protection in Brazil. It established a national law that not only translates the main universal protection clauses to the Brazilian legal system but also enlarges the traditional protection by establishing the possibility of recognizing a person as a refugee due to gross violations of human rights, following the regional formula created in 1984 by the Cartagena Declaration, ${ }^{6}$ which concluded:

3. To reiterate that, in view of the experience gained from the massive flows of refugees in the Central American area, it is necessary to consider enlarging the concept of a refugee, bearing in mind, as far as appropriate and in the light of the situation prevailing in the region, the precedent of the OAU Convention (article 1, paragraph 2) and the doctrine employed in the reports of the Inter-American Commission on Human Rights. Hence the definition or concept of a refugee to be recommended for use in the region is one which, in addition to containing the elements of the 1951 Convention and the 1967 Protocol, includes among refugees persons who have fled their country because their lives, safety or freedom have been threatened by generalized violence, foreign aggression, internal conflicts, massive violation of human rights or other circumstances which have seriously disturbed public order.

Furthermore, it established an administrative RSD procedure in Brazil and a body-the National Committee for Refugees (in Portuguese, Comitê Nacional para Refugiados, or CONARE) - vested with the responsibility of analyzing each individual case. Both of these features were newly introduced by the National Refugee Act.

Prior to 1997 RSD in Brazil was regulated by an interministerial rule, Inter-Ministry Rule 394 (and not by a specific bill), and was conducted mainly by UNHCR. This mechanism was designed in the context of the changing regimen in Brazil. During this period, the state looked for ways to strengthen the application of treaties directed towards the protection of human beings, since this was a factor in acquiring legitimacy within international society. In particular, Brazil suspended some of the reservations it had made to the Refugee Convention and stopped adopting the geographical limitation allowed for in this document. ${ }^{7}$

Recalling the dictatorship regime that existed prior to the mid-1980s in Brazil is key to understanding how RSD in Brazil was built and designed. During this period, despite repression by the military authorities, some NGOs (specifically those linked to the Catholic Church in Rio de Janeiro and São Paulo), with the support of UNHCR, assisted nationals from Argentina, Chile, Uruguay, and Paraguay to get protection in a third country. This action was developed with no support from the state. In fact, the people involved in these assistance actions were risking their lives and liberty, given that some of the people being protected were under military investigation due to their political opinions. This resulted in a very strong bond between Brazilian civil society and UNHCR and in the development of an expertise in refugee protection encompassing both the international community and the internal civil society.

After promulgation in 1988 of the Federal Constitution, which established a regime based on the rule of law, human rights, and democracy, refugee protection started its transformation into a tripartite structure.

In the early 1990s, the development of RSD in Brazil faced the challenge of receiving a large number of asylum seekers from Angola, who left their country due to armed conflict. Most of them were recognized as refugees by the procedure created by the above-mentioned interministerial rule.

This interministerial rule established that UNHCR was to conduct the analysis of individual cases and recommend them (or not) to the Brazilian government for its final approval:

In general the procedure for determining refugee status was as follows: UNHCR interviewed the person seeking refugee status and elaborated a legal opinion recommending, or not, the granting of that status. This legal opinion was then sent to the Ministry of Foreign Affairs, which presented its view on the matter and sent it to the Ministry of Justice, which made the final decision. The decision was then published in the official gazette of the Brazilian government (Diário Oficial da União). ${ }^{8}$

Following this notification, the Federal Police issued an identification document to the refugee.

It is interesting to note that during this period the Brazilian government always followed the legal opinion that was proposed by UNHCR. Furthermore, NGOs linked to the Catholic Church, especially Cáritas Arquidiocesana do 
Rio de Janeiro and Cáritas Arquidiocesana de São Paulo, continued to be the historical partners of UNHCR, being responsible for the actual assistance to and orientation of asylum seekers and refugees.

\section{RSD in Brazil after the 1997 National Refugee Act}

With the approval of the National Refugee Act, there was a substantial change in RSD in Brazil: the transfer of RSD responsibility to the Brazilian government with UNHCR maintaining a supervisory role.

Cáritas Arquidiocesana do Rio de Janeiro and Cáritas Arquidiocesana de São Paulo continued to be part of the new structure, keeping the role of providing reception, assistance, and orientation to asylum seekers and refugees. With the beginning of the resettlement program in Brazil, there was an increase in the number of NGOs working with refugees in Brazil. ${ }^{9}$

The National Refugee Act is the zenith of a process of improving refugee law and protection in Brazil, which had as other landmarks the recognition of UNHCR as an international body in 1982; the approval of the Federal Constitution in 1988; and the lifting of the geographic and temporal restrictions in 1989. It also translates into an increased concern with human rights in the country after the dictatorship, which led to Brazil being more willing to commit to and respect international obligations regarding human rights.

As mentioned, the National Refugee Act defines who is recognized as a refugee in Brazil ${ }^{10}$ and the RSD procedure to be applied. It also establishes the rights and duties of a refugee and the special regimen that applies to people awaiting the decision on RSD-i.e., the asylum seekers (these rights include the impossibility of forced return, deportation, expulsion, or extradition, and the suspension of all administrative and criminal procedures due to irregular entries).

In its fourth title, the National Refugee Act establishes the procedure for RSD in Brazil, stating that:

Art. 17-A foreigner shall appear before a competent authority and state his or her desire to request recognition of the condition of refugee.

Art. 18-The competent authority shall notify the requester to give information and such notification shall set the date for commencement of procedures.

Paragraph One-The competent authority shall inform the United Nations High Commissioner for Refugees- UNHCR on the existence of a proceeding for request for refuge and shall enable UNHCR to offer suggestions to facilitate the development of the proceeding.
Art. 19-In addition to the information, given if necessary with the assistance of an interpreter, a foreigner shall complete a request for recognition as a refugee, including a complete identification, professional qualification, schooling of the requester and members of his or her family group, as well as report on the circumstances and facts that form the basis of the request for refuge, indicating the appropriate evidences

Art. 20-The record of the information and supervision of the request form completion shall be effected by qualified officials and in condition to guarantee information confidentiality. ${ }^{11}$

In light of the above provisions, one can see that the National Refugee Act only establishes the guidelines of RSD in Brazil, reserving an important role to UNHCR.

One of the few impositions of the National Refugee Act regarding RSD is that the decisions on RSD requests are to be made by CONARE, which is a collective deliberative body, as will be further explained below.

Building upon these guidelines, the Brazilian government, UNHCR, and Brazilian civil society have developed a tripartite enterprise regarding RSD which reflects the idea that, for the protection of refugees to be integral, it has to involve the international community, the state, and civil society.

RSD procedure in Brazil begins, as stated above, with the asylum seeker's request for refuge to the competent authority. This authority is the Federal Police, which will formalize the request into a Declaration Term (Termo de Declaração). This document contains the civil qualification of the asylum seeker (name, nationality, name of parents, birthdate) as well as the main reasons for which the asylum seeker left his or her country of origin and is asking for refugee status in Brazil. The date of the Declaration Term is deemed to be the date of the beginning of the procedures.

In order to systematize the procedures, CONARE has established a standard Declaration Term to be followed by the Federal Police throughout the country. ${ }^{12}$ Each adult asylum seeker should have an individual statement taken and written down in a Declaration Term. Children are encompassed in their parent's document.

After having this document issued, the asylum seeker is instructed that he or she has to continue with the proceedings in order to be recognized as a refugee in Brazil. If the asylum seeker remains six months or more without responding to the requests of the proceeding or abandons it, the procedure is archived without having its merits analyzed. ${ }^{13}$

The step following the issuance of the Declaration Term is the completion of a more thorough standard questionnaire. ${ }^{14}$ This step normally takes place at the refugee centres directed by civil society organizations. Nowadays there are two refugee centres in Brazil, directed by Cáritas Arquidiocesana do 
Rio de Janeiro and Cáritas Arquidiocesana de São Paulo. If the asylum seeker is located in a place where there is no refugee centre, the questionnaire is to be filled in at the Federal Police Department. ${ }^{15}$

After the questionnaire is filled in, it is sent to CONARE and the asylum seeker is granted authorization to have a provisory identification issued. This document is the Provisional Protocol (Protocolo Provisório). ${ }^{16}$

The asylum seeker, then, has to go through two interviews. The first interview is conducted by a lawyer from civil society.

In the past, this lawyer was appointed by the Brazilian Bar Association and worked in a partnership between UNHCR and the two mentioned refugee centres. Nowadays, the refugee centres hire the lawyers themselves and UNHCR assists their work by funding their salaries and providing technical support.

The interview is conduct individually and whenever possible in the language of the asylum seeker. When an interpreter is required, the interpreter is instructed about the confidentiality of the proceedings.

The second interview is conducted by a representative of CONARE and follows the same rules as the first interview.

As mentioned above, CONARE is a collective deliberative body. It has both governmental and non-governmental members and the UNHCR has "voice-no-vote" status. The government representatives come from the Ministry of Justice, the Ministry of Foreign Affairs, the Ministry of Health, the Ministry of Labour and Employment, the Ministry of Education and Sports, and the Federal Police. The representative of the civil society comes from an NGO that is involved in the assistance and protection of refugees. Nowadays this seat is occupied by Cáritas Arquidiocesana de São Paulo, with Cáritas Arquidiocesana do Rio de Janeiro being the alternate.

CONARE is presided over by the Ministry of Justice and has a general coordinator that assists its work by organizing the RSD cases to be decided in a plenary meeting with all its members. The general coordinator operates under the umbrella of the Ministry of Justice and is also in charge of the administrative issues regarding refugees, such as the expedition of status declarations, travel authorizations, and authorizations for the issuance of identification documents.

After the two interviews have taken place, there is a meeting by a Preliminary Analysis Group (Grupo de Estudos Prévios) to assess the merits of the case. This step grew out of practice, with the perception that it would be impossible for CONARE to have in-depth analysis of each case in its bimonthly plenary meetings. In order to have each case considered thoroughly, the Preliminary Analysis Group was established. It convenes before CONARE's plenary meeting and does a preliminary analysis of the case, taking into consideration the findings of the civil society's and government's interviews.

The Preliminary Analysis Group consists of CONARE's general coordinator, a representative of the Ministry of Foreign Affairs, a representative of the Federal Police, a representative of UNHCR, and a representative of the civil society organization who has a seat in the CONARE.

With the pre-analysis executed, the cases go to the CONARE's plenary to be decided. In the plenary each member is entitled to one vote, and decisions are made by majority.

If the decision is positive, the asylum seeker is recognized as a refugee in Brazil. If the decision is negative, there is the possibility of an appeal. ${ }^{17}$ This appeal is also an administrative procedure, which has to take place within fifteen days after the asylum seeker is notified of it, in order to be timely. The appeal is analyzed by the Minister of Justice, who gives the final decision on RSD in Brazil. If he changes CONARE's decision, the person is recognized as a refugee; if he does not, the person is subject to the general foreigner's regimen ${ }^{18}$ and is not a refugee in Brazil.

After being recognized as a refugee by CONARE or the Minister of Justice, the refugee has to present herself or himself to the Federal Police Department in order to be registered as a refugee. Before registration, the refugee has to sign a Term of Responsibility (Termo de Responsabilidade), a standard form which was established by CONARE's Normative Resolution 3. ${ }^{19}$ According to this term, the refugee agrees to observe the rules, laws, and provisions aimed at the maintenance of public order and the respect of the rights and duties established by Brazilian law, and attests his or her awareness of being subject to Brazilian civil and criminal law. The refugee also assumes the responsibility of collaborating with Brazilian authorities and humanitarian agencies that assist refugees in Brazil.

The refugee states that he or she is aware of the conditions that may result in the loss of refugee status: (i) proof of falsity during the RSD process; (ii) omission of facts that, if known, should result in a negative decision; (iii) acts against the national security or public order; (iv) leaving Brazilian territory without previous authorization from the Brazilian government.

In regard to the need for authorization to leave Brazilian territory, CONARE's Normative Resolutions ${ }^{20}$ establish the conditions for obtaining an authorization to travel abroad. The refugee shall submit a solicitation to CONARE stating the duration, destination, and reasons of the trip. If necessary, the refugee can ask for a Brazilian passport issued to foreigners, according to provisions of the Foreign Statute Act (Law 6.815, 19 August 1980). 
The principle of family unity does not operate only when all family members become refugees at the same time. Rather, in Brazil, it can be equally applied to cases where a family unit has been temporarily disrupted through the flight of one or more of its members. CONARE's Normative Resolution $4^{21}$ provides for the extension of refugee status through the application of the family unity principle and establishes a standard form of Term of Family Unit Request. According to this resolution, refugee status can be extended to family members (spouse, "ascendant" and "descendant," as well as other elements of the family group who depend economically on the refuge $^{22}$ ), once they are located in the national territory.

Finally, in the spirit of the establishment of durable solutions for refugees living in Brazil, CONARE's Normative Resolution $10^{23}$ ruled on the situation of the refugee who achieves permanent status. In general, the resolution states that even with permanent status, refugee status is continued.

As can be noted by the above description, some of these procedures have been formalized by resolutions of CONARE, but some relevant aspects derive only from practice, as, for instance, the participation of civil society. This has both positive and negative aspects, as, on the one hand, it enables constant improvement, and on the other hand, it may lead to suppression without prior notice of developments that may be seen as guarantees to the refugees. It is important to note, however, that since redemocratization, the trend of refugee law and protection in Brazil has been to evolve, which may minimize this last concern.

\section{Analyzing RSD in Brazil}

Having reviewed RSD procedure in Brazil in the previous section, this section will proceed to analyze it in order to extract lessons, either for its improvement or for the improvement of RSD in general. This analysis is threefold. First it is important to consider RSD in Brazil from an internal standpoint, considering the National Refugee Act, the practice of RSD, and the context in which it occurs. Secondly, the analysis should be made in comparison to the international standards of RSD, i.e. to international refugee law. And finally, bearing in mind that international refugee law is part of a wider system of the protection of the human person (alongside international human rights and international humanitarian law), the analysis of RSD in Brazil should take into consideration whether or not it is in keeping with the most protective standards.

\section{$R S D$ in Brazil in light of the internal context}

First of all the adoption of the National Refugee Act in 1997 must be considered in the context of the redemocratization of Brazil and promulgation of the Federal Constitution in 1988, which considered the primacy of human rights and the concession of political asylum to be guiding principles for Brazil in its international relations (article 4, II and X). This is a key issue because the geographic limitation was suspended just after the Federal Constitution's promulgation, starting the process of developing an internal RSD process in Brazil, which was consolidated in 1997.

Brazil's National Refugee Act is modern and consistent with international standards on refugee protection, being considered as a model to South American countries since the time of its adoption. ${ }^{24}$ It is interesting to observe that some countries, inspired by the Brazilian legislation, issued their own internal rules on refugees, providing for specific situations such as the recognition of refugee status based on reasons of gender, as in the case of Argentina. In Brazil, this aspect has been considered in the broad concept of membership in a particular social group.

Asylum seekers can apply to receive refugee protection all over the country with no cost to them at all. ${ }^{25}$ The decentralization and cost-free nature of the procedure are points to be commended in RSD in Brazil.

The RSD procedure is normally fast: an asylum seeker's request for refugee status usually takes six months to be analyzed by CONARE. In the meantime, asylum seekers receive permission to work, although their language, background experience, and social discrimination are obstacles that they may face in trying to find jobs.

It is important to highlight that RSD procedures in Brazil were developed for examination of claims on an individual basis. This has been satisfactory given that the number of asylum seekers in Brazil is not relatively large, ${ }^{26}$ but the situation could be different in the case of a mass influx of refugees. It would be desirable to create prevention mechanisms in order to avoid a humanitarian crisis in such a situation. However, in RSD in Brazil, there is no procedure for determining eligibility for refugee status on a group basis, rather than through individual screening, when there might be a mass influx or when prevailing conditions might have substantially the same effect upon a large population.

Brazil faced a challenging situation during 2006, when an impressive number (by Brazilian standards) of asylum seekers from Lebanon asked Brazil for protection as refugees. ${ }^{27}$ On that occasion, CONARE decided not to consider the sur place refugee condition of some individuals who were in Brazilian territory when the conflict started, giving a misguided interpretation to that situation. Besides that, because of many fraudulent requests, CONARE decided to apply a "fast-track" procedure for requests by people from Lebanon. This solution, however, did not consider international standards, especially the ExCom Conclusion 30 (XXXIV) of 1983 on the problem of manifestly unfounded or abusive applications for refugee status or asylum, which states: 
(e) Recognized the substantive character of a decision that an application for refugee status is manifestly unfounded or abusive, the grave consequences of an erroneous determination for the applicant and the resulting need for such a decision to be accompanied by appropriate procedural guarantees and therefore recommended that:

(i) as in the case of all requests for the determination of refugee status or the grant of asylum, the applicant should be given a complete personal interview by a fully qualified official and, whenever possible, by an official of the authority competent to determine refugee status

In the case described above, one can see that the fast-track or emergency approach developed by CONARE took into consideration only the interest of the Brazilian government. However, at the other end of the spectrum, one sees that CONARE has used an emergency approach in other circumstances, mainly in order to give a fast response in resettlement cases needing immediate protection.

The fast-track procedure, however, is not ruled by law in any of the cases. This can be regarded as a problem as there is no legal guarantee of the continuity of the procedure in the resettlement cases in the case of a change of government and of public policies in the future. Besides, the fast-track procedure can mean a different treatment for the asylum seeker who arrives in Brazil and asks for refugee status and for the resettled refugee, as the fast track is applied positively almost exclusively to the latter.

The fact that RSD procedure is based mainly on an administrative structure has positive and negative aspects. The expertise of CONARE could have more results if, in fact, the members of CONARE were experts in refugee protection, with advanced knowledge of international and comparative rules. It is true that there has been an effort at capacity building; however, it continues to be limited since there is no attention to the broad system of international law. To determine refugee status, one must consider the inclusion and exclusion clauses, which requires knowledge of other areas of international law, such as international humanitarian law, international criminal law, and international human rights law.

Keeping this limitation in mind, the possibility of judicial review of the RSD decisions is important. In the Brazilian system, there is no legal rule about appeal to the Judiciary in causes related to formal aspects of RSD or to the final decision of the administrative procedure (CONARE and the Minister of Justice). It must be observed that CONARE's decisioneither negative or positive-is limited to stating the recognition or the non-recognition of the condition of "refugee." There is no satisfactory motivation of the decisions. This fact per se denies a basic principle of public administration, and affects the asylum seeker's defense in the case of an appeal, as he or she does not know with certainty the reasons why his or her refugee status request was denied, as the main motivation in the refusal is that the case did not meet "refugee criteria." In this matter it is important to note that, in the few cases that were brought to the Judiciary, this organ said that the statement that the case did not meet "refugee criteria" was enough motivation. ${ }^{28}$

Although the Federal Constitution guarantees access to the Judiciary ${ }^{29}$ in the case of violation or threat to a right, as this is not manifestly stated in the National Refugee Act, few cases are proposed for the consideration of the Judiciary. The result is a precarious judicial jurisprudence on refugee issues in Brazil and unsatisfactory knowledge of the international standards by the members of the Judiciary. In most of the cases in which the Judiciary was called to rule on RSDrelated issues, it referred to CONARE's decision, justifying this action by highlighting the technical expertise of this body, without proceeding to a new analysis of the merits of the case. ${ }^{30}$ Initiatives of training and developing capacity as well as diffusion of international refugee law should be acknowledged, as, for instance, the first course on international refugee law, established in 2007 for university teachers and public attorneys in Rio de Janeiro. ${ }^{31}$

Recognition of participation by civil society as a full member of the CONARE was innovative:

Another distinguishing characteristic of CONARE compared to similar organs in the region is that civil society, represented by an NGO that works with refugees, is not only present but is also entitled to vote. In other countries, these three trends (a representative of a non-governmental organization which works with refugees and is entitled to vote) are not present simultaneously. For example, in Argentina and Uruguay civil society is not represented; in Paraguay the representative of the NGO cannot vote and in Bolivia civil society is represented by the church and by Universidad Mayor de San Andres but there is no mention of the fact that these organs work or have to work with refugees. ${ }^{32}$

Nonetheless it was a reflection of the state of rules based on human rights established by the Federal Constitution of 1988 and the history of refugee protection in Brazil. In fact, if one adopts a more cynical point of view, one could say that the government did not want to assume the entire responsibility for refugees, leaving the practical concern related to the actual reception and integration to the historical experts on the issue-UNHCR and civil society.

Despite the causes that influenced the tripartite design of RSD in Brazil, it presents positive aspects that can not (and should not) be denied. The participation of civil society bal- 
anced the state's concern about national security with the insertion of human concerns into decision making. However, as commented, the participation of civil society has a limited role given that (i) its functioning is not part of the positive law, (ii) an interview of the asylum seeker by CONARE is required, and (iii) in CONARE's plenary meeting it has only one vote.

In addition, the organizations of civil society that are engaged in refugee protection have no institutional common basis to unite them. When they speak up, they mainly do so separately. So, the current initiative to create a national council on refugees (the Brazilian Refugee Council) that unites the legitimized organizations that work with refugee issues assumes a huge relevance. Once established, the Brazilian Refugee Council will have the ability to enhance the position of civil society in CONARE and in the Brazilian government as a whole, and to aid in demanding that the rights of refugees and asylum seekers be fulfilled, that this population's interests be represented in general public policies, and that specific public policies be created respecting the plurality of human beings and the rights of foreign people in conformity with article 5 of the Brazilian Federal Constitution of 1988.

The lack of legal provision on the cooperation of government and civil society ends up generating double efforts and a logistic cost to the asylum seekers related to completion of all the required forms. This cost does not seem to represent a problem to someone with a regular economic condition; however, to an asylum seeker struggling to integrate, it can be insurmountable, notwithstanding the fact that RSD should be free of all costs (direct and indirect).

To sum up, the positive aspects of RSD in Brazil, from the internal point of view, are: participation of civil society (the most important and singular aspect of RSD in Brazil); decentralization; freedom from cost; and democratization of the political dialogue and future endeavours. The negative aspects are: non-legal provision of the exercise of the participation of civil society and the limited role reserved to it; inequality of RSD depending on the place of solicitation (presence or lack of civil society assistance); logistic cost; double efforts; confusion of responsible actors in the perspective of the asylum seeker who does not know the system and therefore has difficulty in grasping the tripartite enterprise; nonlegal provision of mass influx procedure or of an emergency approach; non-legal provision of financial assistance; and co-optation of civil society and individual role played by the civil society actors.

\section{Consistency of RSD in Brazil with International Refugee Law}

Because Brazil is a state-member of the Refugee Convention and its 1967 Protocol, the analysis of the conformity of RSD with international standards will be based on Part Two of the Handbook on Procedures and Criteria for Determining Refugee Status under the 1951 Convention and the 1967 Protocol relating to the Status of Refugees, directed to the procedures for the determination of refugee status. ${ }^{33}$

In view of the situation of different procedures established by states and of the unlikelihood that all states bound by the Refugee Convention and the 1967 Protocol would establish identical procedures, ExCom, at its twenty-eighth session in October 1977, recommended that procedures should satisfy certain basic requirements.

These basic requirements, which reflect the special vulnerability of the asylum seeker and which would ensure that the applicant is provided with certain essential guarantees, are the following:

a. The competent official (e.g., immigration officer or border police officer) to whom the applicant addresses himself or herself at the border or in the territory of a Contracting State should have clear instructions for dealing with cases which might come within the purview of the relevant international instruments. The official should be required to act in accordance with the principle of non-refoulement and to refer such cases to a higher authority;

b. The applicant should receive the necessary guidance as to the procedure to be followed.

c. There should be a clearly identified authority, wherever possible a single central authority, with responsibility for examining requests for refugee status and taking a decision in the first instance.

d. The applicant should be given the necessary facilities, including the services of a competent interpreter, for submitting his or her case to the authorities concerned. Applicants should also be given the opportunity, of which they should be duly informed, to contact a representative of UNHCR.

e. If the applicant is recognized as a refugee, he or she should be informed accordingly and issued with documentation certifying his or her refugee status;

f. If the applicant is not recognized, he or she should be given a reasonable time to appeal for a formal reconsideration of the decision, either to the same or to a different authority, whether administrative or judicial, according to the prevailing system.

g. The applicant should be permitted to remain in the country pending a decision on his or her initial request by the competent authority referred to above, unless it has been established by that authority that his or her request is clearly abusive. $\mathrm{He}$ 
or she should also be permitted to remain in the country while an appeal to a higher administrative authority or to the courts is pending.

As considered before, Brazil has developed a procedure specifically on RSD that conforms to the standards listed above. However, some observations must be made.

Concerning the qualification of the personnel engaged in these procedures there is still a long way to go in order to achieve the ideal level of necessary knowledge and understanding of an applicant's particular difficulties and needs. The National Refugee Act and CONARE's resolutions do not require expert professionals to deal with refugee issues. There are no interpreters who have been through special training. In most cases, a refugee who already has a satisfactory knowledge of Portuguese assists with translation during the interview phase of the RSD procedure when there is difficulty related to language understanding.

Furthermore, there is a difference of reception procedure if one considers the presence of refugee centres in the locality in which the applicant requests refugee status. Usually the asylum seeker will find facilities (Portuguese course, medical treatment, and others) and assistance in Cáritas Arquidiocesana do Rio de Janeiro and Cáritas Arquidiocesana de São Paulo, which leads to the conclusion that the asylum seeker who is located in a city in which there is no Cáritas representation will be in a more vulnerable situation than applicants who can rely on Cáritas, including guidance through all the steps of the RSD procedure and the possibility of being interviewed by a lawyer provided by this organization.

Despite the existence of flaws, one can see an effort on the part of UNHCR and of CONARE to develop capacity regarding refugee issues in the Federal Police Department, which, as mentioned, has an important role in RSD in Brazil. An example of this effort was the creation of seminars for Federal Police members on procedures and criteria on RSD held in eight different cities (São Paulo, Santos, Guarulhos, Curitiba, Foz do Iguaçu, Paranaguá, Manaus and Tabatinga) during 2007. ${ }^{34}$ There are plans to turn this initiative into a continuous effort, always focusing on cities that are ports of entry to Brazil or that have a considerable number of refugees.

The ExCom also expressed the hope that all States Parties to the Refugee Convention and its 1967 Protocol would give favourable consideration to UNHCR participation in such procedures in appropriate form. ${ }^{35}$ As mentioned before, UNHCR has an important role in the Brazilian RSD procedure; nonetheless it does not have the right to vote during the CONARE plenary sessions.
RSD in Brazil and the most protective rules

The National Refugee Act is in general a modern legal instrument. However, as expected of a consensus achieved in a post-dictatorship period and with a foreign status law from 1985 (before redemocratization), it is made up of general provisions. When the "law operator" has to apply the rule to the concrete case, there are many difficulties due to the lack of provisions for special cases or to reluctance to apply human rights rules to cases of asylum seekers and refugees, when they are children, elderly, sick, victims of torture, etc.

In light of this, if one considers the most protective rules, RSD in Brazil has a long way to go, in order to be satisfactory. The following comments illustrate some aspects of this.

First, respect for due process is far from ideal: (i) experience shows that it is extremely difficult to change a decision of CONARE, (ii) there is no procedure of obligatory revision of the CONARE decisions, and (iii) the guarantee of the contradictory is also minimized. On the other hand, CONARE has in the past permitted lawyers to attend its plenary meetings, but this is not the regular situation. There is a common understanding in this body that RSD is not an adversarial procedure and, in consequence, there is no need of a lawyer. This situation contributes to the non-technical character of the CONARE decisions and also to a lack of motivation of the decision, which as seen has not so far being regarded by the Judiciary as a reason for ruling against CONARE's decision. ${ }^{36}$

Secondly, regarding complementary protection, one can see that RSD in Brazil is broader than the universal rules, as the National Refugee Act provides for the recognition of refugee status based on gross violations of human rights. This provision enables RSD to focus not on individual fear of persecution but rather on the situation in the country of origin, and, therefore, enables people coming from a situation of grave and generalized violation of human rights (as for instance from a situation of internal conflict) to be recognized as refugees.

Furthermore, although Brazil does not have a mechanism of temporary protection, CONARE's Normative Resolution 13 of 23 March 2007 provides for the reference of special situations by CONARE to the National Council on Immigration. According to this resolution, the requests for refugee status that can not fulfill the requirements of eligibility under Law $9.474 / 1997$ shall be analyzed by the National Council on Immigration in order to grant a permanent status based on humanitarian conditions.

In this sense one can see that complementary protection is advancing in Brazil, and may make up, in some cases, for the feeble due process guarantees that are in place.

Concerning the protection of vulnerable groups, there are some cases that give rise to special problems in establish- 
ing the facts during the RSD procedure, and because of this, have to count on special legal provisions in order to prevent discrimination and different treatment of similar situations. These are mentally disturbed persons and unaccompanied minors.

In determining refugee status the subjective element of fear and the objective element of it being well-founded need to be established. Mental or emotional disturbances impede a normal examination of the case. A mentally disturbed person may, however, be a refugee, and while that person's claim therefore cannot be disregarded, it should call for different techniques of examination, especially a formal statement of medical advice. Untrue statements by themselves are not a reason for refusal of refugee status and it is the examiner's responsibility to evaluate such statements in the light of all the circumstances of the case. If there is an attested case of legal incapacity (according to the Brazilian Civil Code), a legal representative should be nominated for this person. This has not been the case of RSD in Brazil, where there is no special provision on the rules of a case involving a person with a mental illness. In some cases, when Cáritas is enrolled in the procedure, the asylum seeker can count on special assistance (as for instance medical treatment before the interviews). However, the extent of such assistance is not nearly enough, a situation which is far from desirable.

There is no special provision in the legally binding international refugee instruments regarding the refugee status of persons under age. The same definition of a refugee applies to all individuals, regardless of their age. When it is necessary to determine the refugee status of a minor, problems may arise due to the difficulty of applying the criteria of "well-founded fear" in the case. If a minor is accompanied by one (or both) of his or her parents, or by another family member on whom the minor is dependent and who requests refugee status, the minor's own refugee status will be determined according to the principle of family unity. However, there is still the problem of evidence of paternity considering the need of child protection against trafficking.

The handbook of the UNHCR ${ }^{37}$ says that the question of whether an unaccompanied minor may qualify for refugee status must be determined in the first instance according to the degree of the minor's mental development and maturity. However, in Brazil, the Civil Code and judicial procedures and rules demand that a legal representative be nominated in order to preserve the rights of the unaccompanied minor (under eighteen years old) and to act as a guardian. The international standards stipulate that, in the absence of parents or of a legally appointed guardian, it is for the authorities to ensure that the interests of a minor applicant for refugee status are fully safeguarded.
The problem is that the judicial procedure required to nominate a guardian demands a lot of time, with the result that the minor suffers the insecurity of being in a non-regular status in Brazil, since the minor can not appear alone before the Department of Federal Police in order to make the initial declaration (Term of Declaration). A special procedure shall be determined by law so the best interests of the minor are preserved.

In relation to minors, there are also some difficulties concerning the lack of a birth certificate, which is required by some authorities in order to provide access to education and health treatment services, and also concerning the risk of stateless condition. In fact, stateless cases are not considered in all their aspects and application of the relevant international agreements.

\section{RSD in Brazil-lessons learned?}

From the above, it seems that the most relevant lesson that RSD in Brazil can teach is the importance of having a strong presence of civil society in the proceedings, as this may balance the state's concern with national security as well as help to improve integral protection. However, civil society contributes to the creation of protection links that are too personally based. It is necessary that achievements related to health, education, shelter, etc. assume a legal character in order to provide legal security and a permanent status to the facilities and services.

Civil society is an important actor in defending inclusion of asylum seekers and refugees in general public policies and programs, and also in attributing character of positive law to some of the assistance practices directed to guarantee the rights of children, elders, victims of torture and sexual violence, traumatized persons, etc. Once legal provisions are in place, it is easier for government actors and civil society to prove their violation, hence strengthening the protection of asylum seekers and refugees.

A second lesson that should be highlighted is the importance of having a technical body with knowledge of international law in general, and international refugee law in particular, in charge of RSD. However, there should also be some measure of judicial review in order to rectify mistakes and improve refugee protection.

Also in relation to RSD procedure it seems important to have the most transparent system possible and to have the most protective guarantees in place, regularized by law so that they can not be withdrawn due to political shifts.

Lastly, one cannot highlight enough the importance of training all the actors involved in RSD procedures, especially those in charge of the first approach, in general the staff of the Federal Police Department (Immigration Branch of the Police), and also the staff of NGOs and of the judiciary. Only 
with training will there be awareness of the rights and duties of refugees and asylum seekers, as well as of the special characteristics of this population and the need to have special procedures in place so that they can have their rights really respected.

\section{Conclusion}

Although Brazil has a long way to go in RSD, the basis for dialogue is already in place. It must be consolidated in order to allow for the tripartite structure involving the UNHCR, the Brazilian government, and civil society to be successful in guaranteeing integral protection to refugees and asylum seekers.

The tripartite structure is a model to inspire RSD in other countries given that it permits dialogue and analysis of the problems from different perspectives and the integration of various social protection nets. But it is not enough in itself. These social arrangements of refugees' and asylum seekers' protection must be converted to fundamental rights, so they can be demanded if not respected or implemented, with each participant being receptive to new perspectives and preserving their functional original roles.

The role of civil society in RSD is paramount as it adds a "democratic aspect" to RSD in Brazil, and could stress the humanitarian concerns of the individual cases in order to minimize the national security and labour competitive arguments brought by some government sectors.

The government should keep in mind its international obligations, arising not only from international refugee law but from international law in general, especially humanitarian assistance obligations that are required not only by law but also by any standard of legitimacy.

Lastly, UNHCR has to live up to its role as "guardian" of international refugee law, remembering that the law is only there to protect the people it was designed to assist, so that political and/or economic considerations should be kept to a minimum in light of the humanitarian plea of refugees.

The design of the tripartite RSD is definitely a "best practice" in terms of RSD and refugee protection, but its results must go from the local/subjective to the national/objective (positive law) level, and then become a model to be mutatis mutandis duplicated in other countries.

\section{Notes}

1. Liliana L. Jubilut, O Direito Internacional dos Refugiados e sua aplicação no ordenamento jurídico brasileiro [International refugee law and its application in the Brazilian legal order] (São Paulo: UNHCR; Método, 2007).

2. José Henrique Fischel de Andrade, "O Brasil e a Organização Internacional para Refugiados (1946-1952)” [Brazil and the international organization for refugees] (2005) 48 Revista Brasileira de Política Internacional [Brazilian Journal of International Politics] 60; José Henrique Fischel de Andrade, Direito Internacional dos Refugiados: evolução histórica (1921-1952) [International refugee law: Historical evolution 1921-1952] (Rio de Janeiro: Renovar, 1996).

3. The Refugee Convention was signed by Brazil on 28 July 1951, approved by the Legislature through Decree 11, 7 July 1960, and promulgated by the Executive through Decree 50.215, 28 January 1961. The 1967 Protocol was signed on 31 January 1967, approved by the Legislature through Decree 93, 30 November 1971, and promulgated by the Executive through Decree 70.946, 7 August 1972. The geographic limitation and reserves were only suspended by Decree 98.602, 20 December 1989, and Decree 99.757, 4 December 1990, both issued by the Executive.

4. Law 9.474, 22 July 1997, defines mechanisms to implement the Refugee Convention of 1951 and establishes other provisions.

5. José Henrique Fischel de Andrade and Adriana Marcolini, "A Política Brasileira de Proteção e de Reassentamento de Refugiados-breves comentários sobre suas principais características" [The Brazilian policy of refugee protection and resettlement-Brief comentaries on their main characteristics] (2002) 45 Revista Brasileira de Política Internacional [Brazilian Journal of International Politics] 168.

6. Cartagena Declaration on Refugees, 22 November 1984, Annual Report of the Inter-American Commission on $\mathrm{Hu}-$ man Rights, OAS Doc. OEA/Ser.L/V/II.66/doc.10, rev. 1, at 190-93 (1984-85).

7. As stated by Guy S. Goodwin-Gill and Jane McAdam while explaining the definition of a refugee: "Originally, the definition, [ ... ] limited the application of the Convention to the refugee who acquired such status 'as a result of event occurring before 1 January 1951'. An optional geographic limitation also permitted states, on ratification, to limit their obligations to refugees resulting from 'events occurring in Europe' prior to the critical date"; Guy S. GoodwinGill and Jane McAdam, The Refugee in International Law, $3^{\text {rd }}$ ed. (Oxford: Oxford University Press, 2007), 36.

8. Liliana Lyra Jubilut, "Refugee Law and Protection in Brazil: A Model in South America?” (2006) 19 Journal of Refugee Studies at 26.

9. Brazil received mainly refugees from: Afghanistan who were living in refugee camps in Iran and India; from Colombia, who were under the protection of Ecuador and Costa Rica; and from Palestine, who were living in refugee camps in Jordan. The resettlement initiative has also extended the protection net of civil society in Brazil. Nowadays there are three NGOs that are UNHCR resettlement partners in Brazil: Associação Antônio Vieira (in Porto Alegre, Rio Grande do Sul), Cáritas Brasileira Regional São Paulo (in the state of São Paulo), and Centro de Direitos Humanos e Memória Popular (in Natal, Rio Grande do Norte). UNHCR has a sixth partner in Brazil, which 
is Instituto de Migrações e Direitos Humanos (in Brasília, Distrito Federal).

10. "Art. 1-An individual shall be recognized as a refugee if: I-due to well founded fears of persecution for reasons of race, religion, nationality, social group or political opinions, he or she is out of his or her country of nationality and cannot or does not wish to rely on the protection of such country; II-having no nationality and being out of the country where he or she had previously retained permanent residence, cannot or does not wish to return to such country based on circumstances mentioned in item I above; IIIdue to severe and generalized violation of human rights, he or she is compelled to leave his or her country of nationality to seek in a different country."

11. The text of the National Refugee Act in English is cited based on the information available on the UNHRC Refworld web site, online: <http://www.unhcr.org/cgibin/ texis/vtx/refworld/rwmain?page $=$ country\&amp; docid $=3 \mathrm{f} 4$ dfb134\&amp;skip=\&amp;category=LEGAL\&amp;coi=BR A\&amp;rid=4562d94e2>.

12. CONARE Normative Resolution 1, 27 October 1998, establishes the standard Declaration Term to be completed by the Federal Police Department on the occasion of the request for refugee status. Furthermore, it states that this document shall be sent to the General Coordination of CONARE, with a copy to the Caritas Arquidiocesana, aiming the fulfillment of the questionnaire in order to make possible the analysis of the refugee solicitation.

13. CONARE Normative Resolution 11, 29 April 2005, provides for the publication of the notification established by article 29 of Law 9.474, 22 July 1997 (deadline for certain procedures and for attending to official notifications). This resolution revoked CONARE Normative Resolution 7, 6 August 2002. If CONARE has already issued a negative decision and the asylum seeker can not be found in order to receive the notification, the decision shall be published by the official press for the purpose of establishing the deadline for appeal.

14. CONARE Normative Resolution 2, 27 October 1998, establishes the standard questionnaire for refugee status request, which shall be completed by the asylum seeker at the headquarter of the Caritas Arquidiocesana and sent to the General Coordination of CONARE in order to continue with the procedures. In a location where there is no Caritas representation, the completion of the questionnaire shall be arranged by the Federal Police Department and the questionnaire sent to CONARE along with the Term of Declaration. Although there is no provision for the language in which the questionnaire is to be available, it is available in Portuguese, English, French, and Spanish. An asylum seeker who does not speak any of these languages can be aided by a translator, who is not part of the regular staff of the institutions enrolled in the process.

15. CONARE Normative Resolution 9, 6 August 2002, establishes the place for completion of the questionnaire for re- questing refugee status in the localities in which there is no representation of Caritas Arquidiocesana.

16. CONARE Normative Resolution 6, 26 May 1999, provides for the concession of a protocol to asylum seeker. Once the asylum seeker has the Provisional Protocol, he or she is entitled to have a labour license and a document relevant for financial purposes called the Register of Natural Persons (Cadastro de Pessoas Físicas, or CPF); so that he or she can begin to integrate into Brazilian society more fully.

17. CONARE Normative Resolution 8, 6 August 2002, provides for notification of the request of the refugee status. If the asylum seeker can not be found after six months from the date of the CONARE decision to receive the notification, the negative decision of the refugee status request shall be published in the official press.

18. The Statute of Foreigner (Law 6.815, 19 August 1980, establishes the legal situation of foreigner in Brazil, and creates the National Council of Immigration). Decree 86.815, 10 December 1981, rules the Law 6.815/80, which establishes the legal situation of foreigner in Brazil and creates the National Council of Immigration and stipulates other provisions.

19. CONARE Normative Resolution 3, 27 October 1998, establishes the standard form Term of Responsibility which has to be signed by the refugee before his or her register into the Federal Police Department. The competent authority shall provide an interpreter if necessary so the refugee has knowledge of the content of the Term.

20. CONARE Normative Resolution 5, 11 March 1999, provides for authorization to travel to abroad. CONARE Normative Resolution 12, 29 April 2005, provides for authorization for a refugee to travel abroad; for issuing of a Brazilian passport to a refugee foreigner, when necessary; and for processing of the loss of refugee status because of leaving Brazilian territory without authorization.

21. CONARE Normative Resolution 4, 11 March 1999, establishes the extension of refugee status through the application of the family unit principle.

22. For the purpose of the resolution, "dependants" must be understood as: the spouse; the single son/daughter, under twenty-one years old, including those adopted, or older than twenty-one years old when they can not provide for themselves; ascendant; and sisters/brothers, grandsons/ granddaughters, great-grandson/great-granddaughter, nephew/niece, only if they are orphans, single, and under twenty-one years old, or of any age when they can not provide for themselves. The situation of economic dependency of a person older than twenty-one years who cannot provide for her/himself has to be related to physical and mental health and must be declared by a doctor. The minor children whose parents are detained or have disappeared must be considered in the same situation as orphans.

23. CONARE Normative Resolution 10, 22 September 2003, provides for the situation of the refugee who achieves permanent status. 
24. Supra note 31 .

25. Only when recognized they will have to pay the required amount in order to have a refugee identification document issued. Currently a judicial provisional measure suspends this payment if the foreigner states her or his economic condition.

26. According to CONARE, during 2007 Brazil received fewer than 500 requests for refugee status, and as of June 2008, Brazil hosted 3,513 refugees.

27. For details, see the position of Cáritas Arquidiocesana de São Paulo on asylum seekers from Lebanon: Cáritas Arquidiocesana de São Paulo, Documento entregue na Reunião do CONARE de 23.03.2007 [Legal position presented at CONARE'S meeting of March 23, 2007], Posição da Cáritas Arquidiocesana de São Paulo sobre Solicitantes e Refúgio Libaneses [Cáritas Arquidiocesana de São Paulo position on asylum seekers from Lebanon].

28. For instance the decision of the Superior Court of Justice (Superior Tribunal de Justiça) in: Agravo Regimental no Agravo Regimental do Mandado de Segurança 12.212/DF, cited in Liliana L. Jubilut, O Direito Internacional dos Refugiados e sua aplicação no ordenamento jurídico brasileiro [International refugee law and its application in the Brazilian legal order], supra note 1 at 103. (Agravo Regimental is a special appeal according to specific court regulations only available for Superior Courts. Mandado de Segurança is the writ of security or the writ of mandamus.)

29. Federal Constitution 1988, article 5, XXXV: "the law shall not exclude from review by the Judiciary any violation of or threat to a right."

30. For instance the decisions of the Superior Court of Justice in: Agravo Regimental do Mandado de Segurança 12212/ DF; Habeas corpus 36033/DF; and Habeas corpus 32622/DF, cited by Liliana L. Jubilut, O Direito Internacional dos Refugiados e sua aplicação no ordenamento jurídico brasileiro, [International refugee law and its application in the Brazilian legal order], supra note 1 at 103.

31. Liliana Lyra Jubilut and Silvia Menicucci Apolinarion (organizers). I Course on International Refugee Law, realized in December 2007 at the Centre of Human Rights, Department of Law, PUC-Rio.

32. Supra note 7 at 33 .
33. HCR/IP/4/Eng/REV.1 Reedited, Geneva, January 1992, UNHCR 1979. The UNHCR also developed a handbook on procedural standards for refugee status determination under UNHCR's mandate, in which it considers general issues, reception and registration in RSD operations, adjudication of refugee claims, processing claims based on the right to family unity, notification of RSD decisions, appeal of negative RSD decisions, UNHCR refugee certificate, procedures for file closure / re-opening, procedures for cancellation of refugee status, and procedures for cessation of refugee status. See "Procedural Standards for Refugee Status Determination under UNHCR's Mandate," < http:// www.unhcr.org/publ/PUBL/4316f0c02.html>.

34. In the cities of São Paulo, Santos, and Guarulhos the seminar was offered with the support and participation of Cáritas Arquidiocesana de São Paulo.

35. Such participation is based on article 35 of the Refugee Convention and the corresponding article 11 of the 1967 Protocol, which provide for co-operation by the Contracting States with the High Commissioner's Office.

36. The decision of the Superior Court of Justice in: Agravo Regimental no Agravo Regimental do Mandado de Segurança 12.212/DF cited in Liliana L. Jubilut, O Direito Internacional dos Refugiados e sua aplicação no ordenamento jurídico brasileiro, [International refugee law and its application in the Brazilian legal order], supra note 1 at 103.

37. Handbook on Procedural Standards for Refugee Status Determination under UNHCR's Mandate.

Liliana Lyra Jubilut holds a Ph,D. in international law from Universidade de S. Paulo, and an LL.M. in international legal studies from NYU School of Law, and is Professor of International Law and Human Rights at Faculdade de Direito do Sul de Minas. Silvia Menicucci de Oliveira Selmi Apolinário holds a Ph.D. in international law from Universidade de S. Paulo, and is Professor of International Law and Human Rights at PUC-Rio (Rio de Janeiro) and International Humanitarian Law at UniCEUB (Brasilia). Both authors were lawyers at the refugee centres in S. Paulo and Rio de Janeiro and were directly involved in RSD in Brazil. 